\title{
Intrapopulation variation in shell morphological traits and banding polymorphism of the land snail Cepaea vindobonensis (Gastropoda; Pulmonata; Helicidae)
}

\author{
A.S. Kramarenko ${ }^{1}$, Zh.V. Ignatenko ${ }^{1}$, O.I. Yulevich $^{1}$, Y.V. Barkar ${ }^{1}$, A.V. Markowska ${ }^{1}$, \\ O.O. Salamatina ${ }^{1}$, V.M. Stamat ${ }^{1}$, S.S. Kramarenko ${ }^{1}$
}

${ }^{1}$ Mykolayiv National Agrarian University, Georgiy Gongadze Str., 9, Mykolayiv, 54020 Ukraine

*Corresponding author E-mail: kssnail0108@gmail.com

Received: 08.09.2020. Accepted 13.10.2020

\begin{abstract}
The main goal of this paper was to analyze intrapopulation variation of both morphological traits and shell banding polymorphism using the example of a continuous population (a metapopulation) of the land snail Cepaea vindobonensis (Férussac, 1821). A total of 14 samples of the land snail $C$. vindobonensis from a population located in the "Dubki" Park (Ukraine, Mykolayiv) were collected in May-July 2007. The land snail collection sites are divided into three areas by buildings and asphalt roads, indicated by the Latin letters A, B and C. The major diameter of shell (MJD), the minor diameter of shell (MID) and the shell height (SH) were measured with a digital calliper to the nearest $0.05 \mathrm{~mm}$. Two shell shape indices (SF1 and SF2) were also computed.

A high level of the intrapopulation variation of the land snail $C$. vindobonensis was found in our study. Significant differences between sample means were found for all shell traits and indices used (except for SF1), however, maximum difference was noted for SH and SF2 (in both cases: $P<0.001$ ). About $80 \%$ of the total variation of the variance-covariance matrix was explained by the $1^{\text {st }}$ and $2^{\text {nd }}$ Principal Components (PC1 and PC2). The PC1 was characterized by high positive factor loadings of MJD, MID and SH and thus can be interpreted as "shell size dimension" and the PC2 had a high correlation with SF2 and thus it can be interpreted as "shell globularity". The PC1 and PC2 determined a high level of spatial differentiation of intrapopulation morphological variation of the land snail C. vindobonensis. Samples with small (area A) and large (areas B and C) shells were separated from each other according to the PC1. Areas B and $C$ were characterized by individuals with flatness and globularity shells, respectively.

The areas $A, B$ and $C$ differed significantly in the total number of morphs, average number of morphs and frequency of rare morphs (Kruskal-Wallis $\mathrm{H}$-test; in all cases $P<0.010$ ). At the same time, the highest value of phenetic diversity was noted for samples collected within $A$ and $C$ areas. In general all phenetic diversity estimators showed a positive correlation with sample size (Spearman's correlation coefficient; in all cases $P<0.05$ ). It was found that the type of biotope did not likely affect the frequency of individual morphs with respect to the shell banding polymorphism pattern. With regard to the most common morphs two patterns of the spatial arrangement of the intrapopulation variation were found - clinal pattern was for the frequency of pallescens morph and chaotic pattern was for frequency of "12345" morph.
\end{abstract}

Keywords: Intrapopulation variantion; Shell morphological traits; Shell Banding polymorphism; Land snail; Cepaea vindobonensis

\section{Introduction}

Many species of the molluscs display an uncommon phenotypic plasticity with high interpopulation and intrapopulation morphological variability, which could be advantageous for coping with habitat modifications (Van Marion, 1981; Harvey \& Vincent, 1991; Yusseppone et al., 2018). Analysis of intrapopulation morphometric variation in Pisidium subtruncatum Malm, 1855 (Bivalvia) showed that variability is higher in habitats with high temporal and spatial environmental variability and lower in habitats with low or reduced environmental heterogeneity (Funk \& Reckendorfer, 2008). The functional significance of the variability found in the shell shape variation in the Nassariid Buccinanops globulosus (Kiener, 1834) (Gastropoda) has been discussed in terms of the flexibility of developmental programmes for morphology as well as the evolution of phenotypic plasticity (Avaca et al., 2013).

Land snails are an ideal model object for studying the processes of genetic intrapopulation fine-scale spatial differentiation and subdivision (Zhukov et al., 2019). Their population size are always large, but in space individuals are often distributed overcrowded, the migratory/invasive capacity is low, but passive dispersal (incl. due to anthropochory) is a common phenomenon, and their shell partially preserves the results of early phase of ontogenesis and can be stored for decades. In addition, the land snail shell reflects the manifestation of genetic variation in quantitative and qualitative traits (Clarke et al., 1978).

Variation of the shell size and shape in land snails, in most situations is considered from the taxonomic point of view and used to identify cases of inter(sub)specific differences in taxonomically related groups. (Armbuster, 1995; Chiba, 1998; Giokas, 2000; Gould \& Woodruff, 1985; Jordaens et al., 2009; Woodruff \& Gould, 1980). Much less attention is paid to the manifestations of intraspecific and intrapopulation variation, as well as to the search for causes and patterns of their formation. The last detailed review of cases of the land snails intraspecific variation in shell shape and shell size with special consideration of its causes was given more than 30 years ago (Goodfriend, 1986). However, a large amount of actual material, which illustrates the formation of different patterns of the conchological variation among numerous species of land snails, has been accumulated over the last few years (see review Kramarenko, 2016). 
The simple sampling pattern still prevails in the analysis of interpopulation variation where each population is characterized by one single sample (it sometimes contains a small number of specimens). However, earlier we noted a high level of conchiometric variation within continuous populations (metapopulations) of a land snail Brephulopsis cylindrica (Menke, 1828). Generally, the intrapopulation shell size and shape variation component is nearly $1 / 5$ from the sum of the intra- and interpopulation variation (Kramarenko, 2016).

Thereby the change in sampling strategy from "single population - single sample" to "single population - several samples" has been required. However in such event, the analysis of interpopulation differentiations (i.e. early stages of an infra-species diversification) should be organized in form of nested ANOVA, namely, several independent samples must be collected within a studied population (Kramarenko \& Dovgal, 2014).

Accordingly, the main goal of this paper was to analyze intrapopulation variation of both morphological traits and shell banding polymorphism using the example of a continuous population (a metapopulation) of the land snail Cepaea vindobonensis (Férussac, 1821).

\section{Materials and Methods}

We collected 14 samples of land snail C. vindobonensis from "Dubki" Park (Ukraine, Mykolayiv, 46.9796, 32.069) in May-July 2007. The plot was $800 \mathrm{~m}$ in length and $400 \mathrm{~m}$ in width. The park was more or less equable artificial oak planting with occasional bush thickets. The land snail sites were divided into three areas by buildings and asphalt roads, indicated by the Latin letters $A$, B and C (Figure 1).

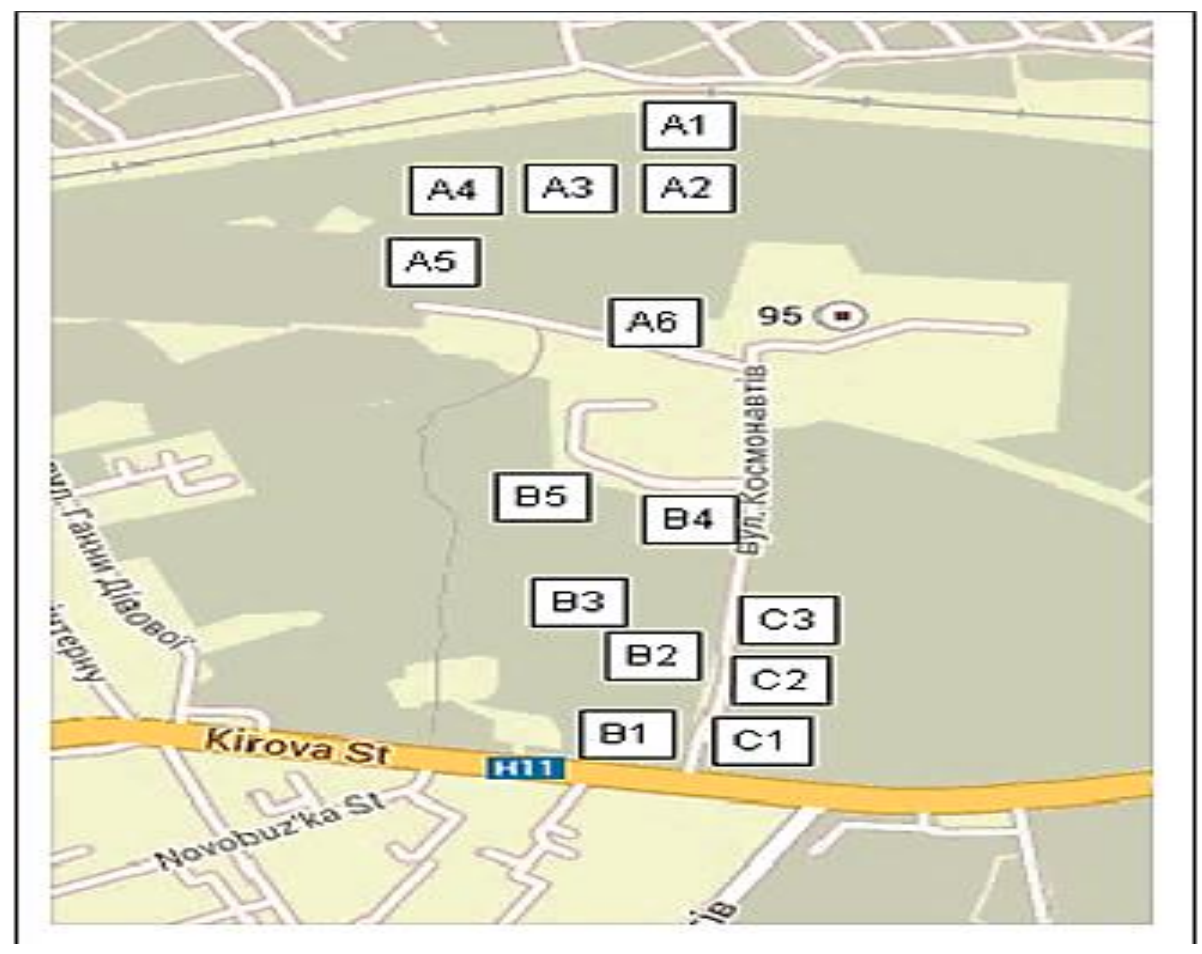

Figure 1. Map of sampling sites for the land snail C. vindobonensis in the "Dubki" Park.

Only adult individuals (and their empty shells) of the land snail $C$. vindobonensis with shell aperture with reflected lip were collected. In each sample, the specimens (and their empty shells) were taken within an area of approximately $25 \mathrm{~m}^{2}$. On average, each sample contained about a hundred snails (or their shells), but the size of individual samples ranged from 46 to 184 individuals.

Thirty shells were randomly selected from each sample. The major diameter of shell (MJD), the minor diameter of shell (MID) and the shell height (SH) were measured with a digital calliper to the nearest $0.05 \mathrm{~mm}$ according to Sverlova et al. (2006). Two shell shape indices, SF1 (= MJD/MID) and SF2 (= SH/MJD), were also computed.

The analysis was conducted using the descriptive statistics (Mean $\pm S E$ ) of the shell traits and indices for each sample. To compare the degree of morphological differentiation within and between areas, the nested ANOVA was used for all shell traits and indices of the land snail $C$. vindobonensis. For Principal Components Analysis (PCA) the three morphometric traits and the two shell shape indices, mentioned above, were used to reduce the dimensionality of the highly correlated morphological data.

The peculiarities of snail shell banding polymorphism were analyzed in laboratory conditions. In this case, different morphs were denoted by the conventional system (Cain \& Sheppard, 1950). The shell's bands were numbered from " 1 " to " 5 ", counting from the suture between the last and penultimate whorls to the umbilicus. In the absence of a band (or several bands), the number in their formula was zero. In the case of fusion two or more bands, their numbers in the formula are combined with parentheses.

In addition, two indicators of intra-population diversity - the average number of morphs $(\mu \pm S E \mu)$ and the frequency of rare morphs $\left(h_{\mu} \pm S E h_{\mu}\right)$ - were calculated based on the formulas (Zhivotovsky, 1991):

$$
\begin{gathered}
\mu=\left(\sum_{i=1}^{m} \sqrt{p_{i}}\right)^{2}, \\
S E_{\mu}=\sqrt{\frac{\mu(m-\mu)}{n}},
\end{gathered}
$$




$$
\begin{aligned}
& h_{\mu}=1-\frac{\mu}{m}, \\
& S E_{h_{\mu}}=\sqrt{\frac{h_{\mu}\left(1-h_{\mu}\right)}{n} .}
\end{aligned}
$$

The Chi-square tests of significant differences in morph frequencies as between areas, as among sites within areas were computed using the program PAST 2.14 (Hummer et al., 2001).

The Moran's spatial autocorrelation index (Moran's I) was measured to describe of micro-spatial patterns of the morphological variation. Spatial autocorrelation is defined as the association of the values of one geographically distributed variable with the values of the same variable at other localities (Sokal \& Oden, 1978). Thus, spatial autocorrelation coefficients index (Moran's I) is the expression of similarities between neighboring locations (Moran, 1950). All statistical procedures were done with SAM v. 4 software (Spatial Analysis in Macroecology, Rangel et al., 2006).

\section{Results}

\section{Intrapopulation morphological variations}

The shell traits and indices for 14 sites within studied population of the land snail $C$. vindobonensis are presented in Table 1. Significant differences between sample means were found for all shell traits and indices used (except for SF1), however, maximum difference was noted for SH and SF2 (in both cases $P<0.001$ ). Clear spatial differentiation was noted only for shell size (Table 1 ). The largest diameter of shell was recorded among $C$. vindobonensis, which inhabited B and $C$ areas, while molluscs with the smallest diameter were found in area A. With respect to shell height, the largest in size individuals of $C$. vindobonensis inhabited area $B$, and individuals with a minimum shell height were most commonly found in area A. For SF2, the chaotic pattern in spatial arrangement of the intrapopulation morphological differentiation was noted. Within same areas, $C$. vindobonensis samples with both minimum and maximum values of this index were marked (Table 1). Results of the nested ANOVA of the shell traits and indices for 14 sites within studied population of the land snail $C$. vindobonensis are presented in Table 2. A strong influence of the "area" factor was noted for all shell traits and indices used (except for SF1), while SH and SF2 were characterized by a significant level of variation among sites within areas.

\begin{tabular}{|c|c|c|c|c|c|c|c|c|c|c|}
\hline \multirow[t]{3}{*}{ Site } & \multicolumn{10}{|c|}{ Shell trait and index } \\
\hline & \multicolumn{2}{|c|}{ MJD (mm) } & \multicolumn{2}{|c|}{ MID (mm) } & \multicolumn{2}{|c|}{ SH (mm) } & \multicolumn{2}{|c|}{ SF1 } & \multicolumn{2}{|c|}{ SF2 } \\
\hline & Mean & SE & Mean & $S E$ & Mean & SE & Mean & SE & Mean & $S E$ \\
\hline $\mathrm{A} 1$ & 22.83 & 0.26 & 19.75 & 0.21 & 16.32 & 0.19 & 1.156 & 0.006 & 0.715 & 0.006 \\
\hline $\mathrm{A} 2$ & 23.21 & 0.15 & 19.89 & 0.14 & 15.98 & 0.15 & 1.167 & 0.003 & 0.688 & 0.004 \\
\hline A3 & 22.78 & 0.17 & 19.61 & 0.17 & 16.10 & 0.16 & 1.162 & 0.007 & 0.707 & 0.007 \\
\hline A4 & 22.73 & 0.15 & 19.65 & 0.14 & 16.53 & 0.14 & 1.157 & 0.006 & 0.728 & 0.004 \\
\hline A5 & 22.80 & 0.17 & 19.67 & 0.12 & 15.79 & 0.13 & 1.160 & 0.007 & 0.693 & 0.006 \\
\hline A6 & 23.08 & 0.18 & 20.08 & 0.15 & 15.93 & 0.16 & 1.150 & 0.007 & 0.691 & 0.006 \\
\hline B1 & 22.95 & 0.18 & 19.78 & 0.14 & 15.77 & 0.12 & 1.160 & 0.004 & 0.688 & 0.004 \\
\hline B2 & 23.10 & 0.21 & 19.91 & 0.14 & 16.34 & 0.16 & 1.160 & 0.006 & 0.708 & 0.007 \\
\hline B3 & 23.19 & 0.15 & 19.98 & 0.12 & 16.64 & 0.12 & 1.161 & 0.004 & 0.718 & 0.005 \\
\hline B4 & 23.37 & 0.20 & 20.18 & 0.13 & 16.52 & 0.14 & 1.158 & 0.006 & 0.708 & 0.006 \\
\hline B5 & 23.20 & 0.12 & 20.07 & 0.12 & 16.52 & 0.15 & 1.156 & 0.004 & 0.712 & 0.005 \\
\hline $\mathrm{C} 1$ & 23.04 & 0.16 & 19.80 & 0.15 & 16.26 & 0.17 & 1.164 & 0.006 & 0.706 & 0.007 \\
\hline $\mathrm{C} 2$ & 23.26 & 0.19 & 20.30 & 0.18 & 15.67 & 0.15 & 1.147 & 0.007 & 0.674 & 0.006 \\
\hline $\mathrm{C} 3$ & 23.59 & 0.16 & 20.14 & 0.16 & 16.27 & 0.18 & 1.172 & 0.005 & 0.690 & 0.008 \\
\hline F(13; 406) & \multicolumn{2}{|c|}{1.93} & \multicolumn{2}{|c|}{2.05} & \multicolumn{2}{|c|}{4.40} & \multicolumn{2}{|c|}{1.19} & \multicolumn{2}{|c|}{6.27} \\
\hline$P$ & \multicolumn{2}{|c|}{0.025} & \multicolumn{2}{|c|}{0.016} & \multicolumn{2}{|c|}{$<0.001$} & \multicolumn{2}{|c|}{ ns } & \multicolumn{2}{|c|}{$<0.001$} \\
\hline
\end{tabular}

Table 1. The shell measurements (Mean $\pm S E$ ) for 14 sites with population of Cepaea vindobonensis.

ns: not significant $(P>0.05)$.

Table 2. Results of the nested ANOVA of the shell measurements for 14 sites with population of $C$. vindobonensis.

\begin{tabular}{lcc}
\hline Shell trait and index & Between areas & $\begin{array}{c}\text { Source of variation } \\
\text { Among sites within areas } \\
\boldsymbol{F}_{\mathbf{1 1 ; 4 0 6}}(\boldsymbol{P})\end{array}$ \\
\hline MJD & $\boldsymbol{F}_{\mathbf{2 ; 4 0 6}}(\boldsymbol{P})$ & $1.25(\mathrm{~ns})$ \\
MID & $5.68(0.004)$ & $1.55(\mathrm{~ns})$ \\
SH & $4.82(0.009)$ & $4.31(<0.001)$ \\
SF1 & $4.94(0.008)$ & $1.38(\mathrm{~ns})$ \\
SF2 & $0.17(\mathrm{~ns})$ & $5.99(<0.001)$ \\
\hline
\end{tabular}

Factor loadings for the PC's on the shell traits and indices of the land snail $C$. vindobonensis based on the Principal Component Analysis are presented in Table 3 . About $80 \%$ of the total variation of the variance-covariance matrix was explained by the $1^{\text {st }}$ and $2^{\text {nd }}$ Principal Components. The Principal Component 1 (PC1) was characterized by high positive factor loadings of MJD, MID and SH and thus can be interpreted as "shell size dimension". The Principal Component 2 (PC2) had a high correlation with SF2 and thus it can be interpreted as "shell globularity". 
Table 3. Factor loadings for the PC's on the shell traits and indices of $C$. vindobonensis.

\begin{tabular}{|c|c|c|}
\hline \multirow[t]{2}{*}{ Shell trait and index } & \multicolumn{2}{|c|}{ Principal Component } \\
\hline & PC1 & PC2 \\
\hline MJD & 0.858 & 0.510 \\
\hline MID & 0.896 & 0.085 \\
\hline $\mathrm{SH}$ & 0.816 & -0.438 \\
\hline SF1 & -0.030 & 0.657 \\
\hline SF2 & 0.148 & -0.924 \\
\hline$\%$ cumulative variation & 44.51 & 34.92 \\
\hline
\end{tabular}

The PC1 and PC2 determined a high level of spatial differentiation of intrapopulation morphological variation of the land snail C. vindobonensis. Samples with small (area A) and large (areas B and C) shells were separated from each other according to the PC1 (Figure 2A). Areas B and C were characterized by individuals with flatness and globularity shells, respectively (Figure 2B).

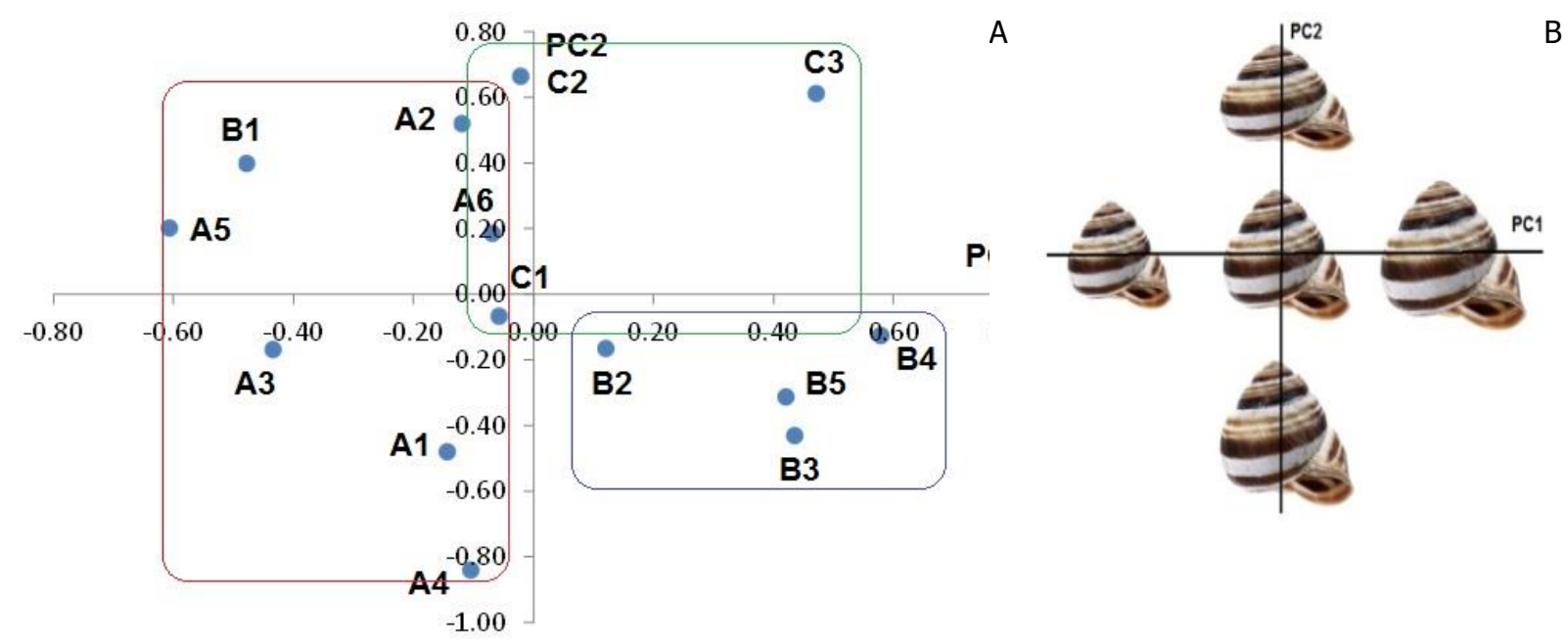

Figure $2 \mathrm{~A}$. Scattered plot for the $1^{\text {st }}$ and $2^{\text {nd }}$ Principal Components in 14 sites with population of $C$. vindobonensis. B. General scheme of interpretation for the $1^{\text {st }}$ and $2^{\text {nd }}$ Principal Components.

Moran's index for morphometric shell traits and indices within studied population of the land snail are presented in Figure 3. For MJD and MID there is high positive autocorrelation for the smallest lags and gradual decrease of Moran's index of spatial autocorrelation with increasing distance between sites (up to negative values). This indicates the formation of a clearly defined clinal pattern in spatial arrangement of the intrapopulation morphological variation. Whereas for SH and two shell shape indices, the main characteristic of spatial variation within the studied population of $C$. vindobonensis had completely random nature, as evidenced by the shape of their correlograms and the absence of significant values of Moran's index of spatial autocorrelation (Figure 3).

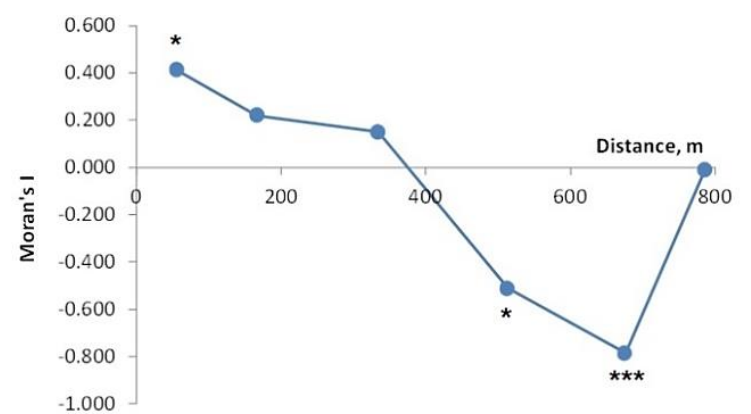

A

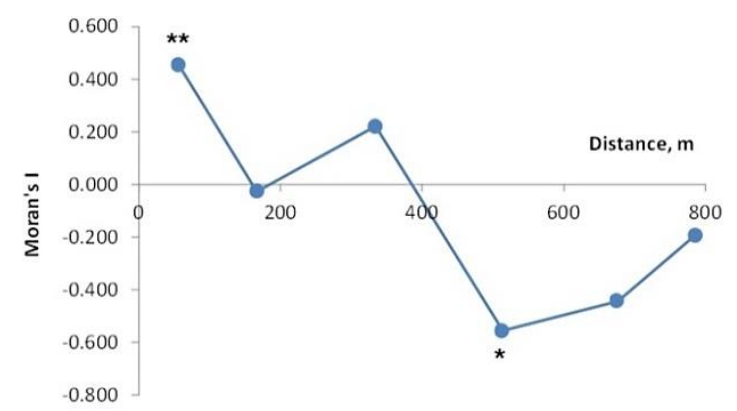



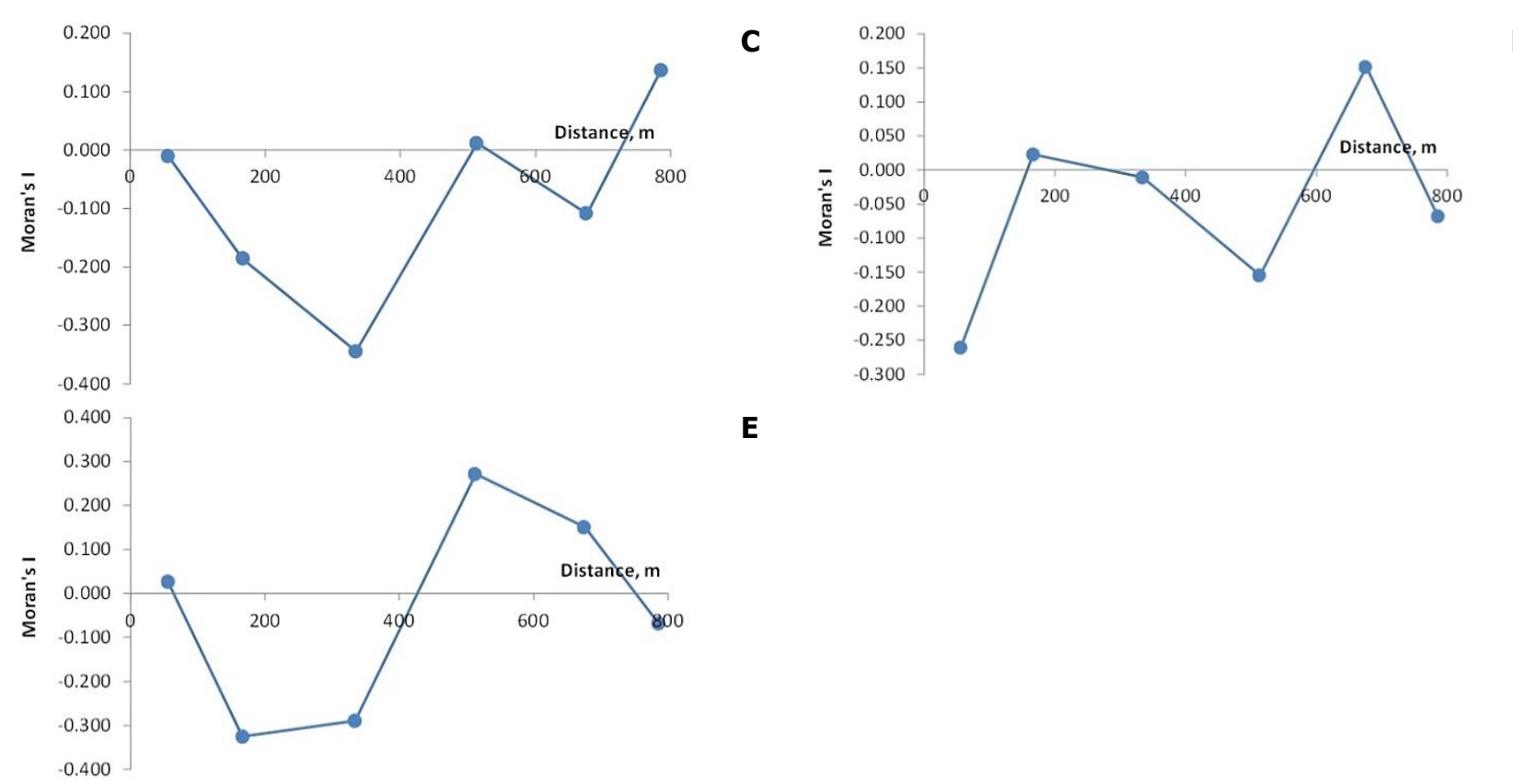

Figure 3. Moran's index for morphometric shell traits and indices within population of $C$. vindobonensis. A - MJD; B - MID; C - SH; D - SF1; E - SF2. (Significant values of Moran's index indicated as solid circles: $* P<0.05, * * P<0.01, * * * P<0.001$ ).

\section{Intrapopulation shell banding polymorphism}

For $C$. vindobonensis two types of polymorphism were considered: in relation to the shell colour and to banding polymorphism. In the first case, all shells were divided into two groups: the first one included shells with a sandy-green colour with light bands (pallescens morph), and in the second group there were shells with almost white background, on which clearly dark brown or black pigment bands are visible. In total, ten morphs in the shell banding polymorphism of the land snail $C$. vindobonensis were registered in the studied population. Two roads that divided the collection sites into three areas, made a significant contribution to the formation of the microspatial phenetic structure of the land snail $C$. vindobonensis population. In area $A$, the frequency of pallescens morph among the samples was very low (0.013...0.210; average: 0.099$)$, and in area B, on the contrary, very high (0.217...0.791; average: 0.626 ). Samples in area C occupied an intermediate position with a frequency of pallescens morph of $0.295 . . .0 .359$ (average: 0.326$)$. Statistically significant difference between the frequency of pallescens morph of the land snail $C$. vindobonensis was noted between separate areas $\left(X^{2}=302.08 ; d f=2 ; P<0.001\right)$ and also among sites within studied areas $\left(x^{2}=83.16 ; d f=\right.$ $11 ; P<0.001)$. In regard to the most common morph ("12345"), significant difference was observed only between these areas $\left(X^{2}\right.$ $=13.80 ; d f=2 ; P=0.001)$, while there was no significant difference among sites within areas $\left(X^{2}=15.17 ; d f=11 ; P=0.175\right)$. A similar result was noted for the morph "(12)3(45)" for which significant difference was noted only between areas $\left(\chi^{2}=11.93 ; d f=\right.$ $2 ; P=0.003$ ). Noteworthy is the fact that (with the only exception) all specimens of the land snail $C$. vindobonensis with this morph were found only in area $C$. Among morphs with fused bands, significant difference between areas was found for morph " $F(23)$ " $\left(X^{2}\right.$ $=13.73 ; d f=2 ; P=0.001$ ); individuals of this morph were registered only (with only one exception) within $\mathrm{A}$ and $\mathrm{C}$ areas. In all the cases described above, significant differences among sites within studied areas were not revealed.

Three these areas and all sites were also differed in estimates of the general phenetic diversity of Zhivotovsky. The highest average number of morphs $(\mu=3.12 \pm 0.31)$ was recorded in the sample from the site $\mathrm{C} 2$, while the lowest score $(\mu=1.00)$ was registered within sites B3 and B4. The areas A, B and C differed significantly in the total number of morphs, average number of morphs and frequency of rare morphs (Kruskal-Wallis $\mathrm{H}$-test; in all cases $P<0.010$ ). At the same time, the highest value of phenetic diversity was noted for samples collected within $\mathrm{A}$ and $\mathrm{C}$ areas.

In general all phenetic diversity estimators showed a positive correlation with sample size (Spearman's correlation coefficient; in all cases $P<0.05)$. In relation to the frequency of rare morphs, this dependence has asymptotic behavior, i.e., at $n>60 . . .80$, this indicator value not changed any more (Figure 4A). A similar curvilinear relationship was also observed between the total number of morphs and the frequency of rare morphs in samples of the land snail $C$. vindobonensis within the studied population (Figure 4B).

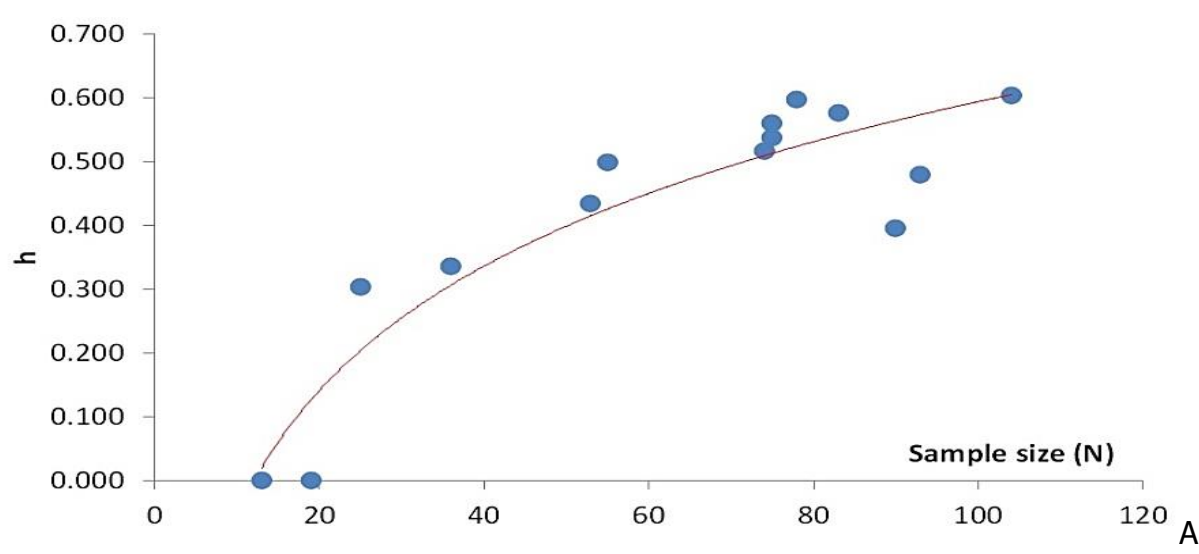




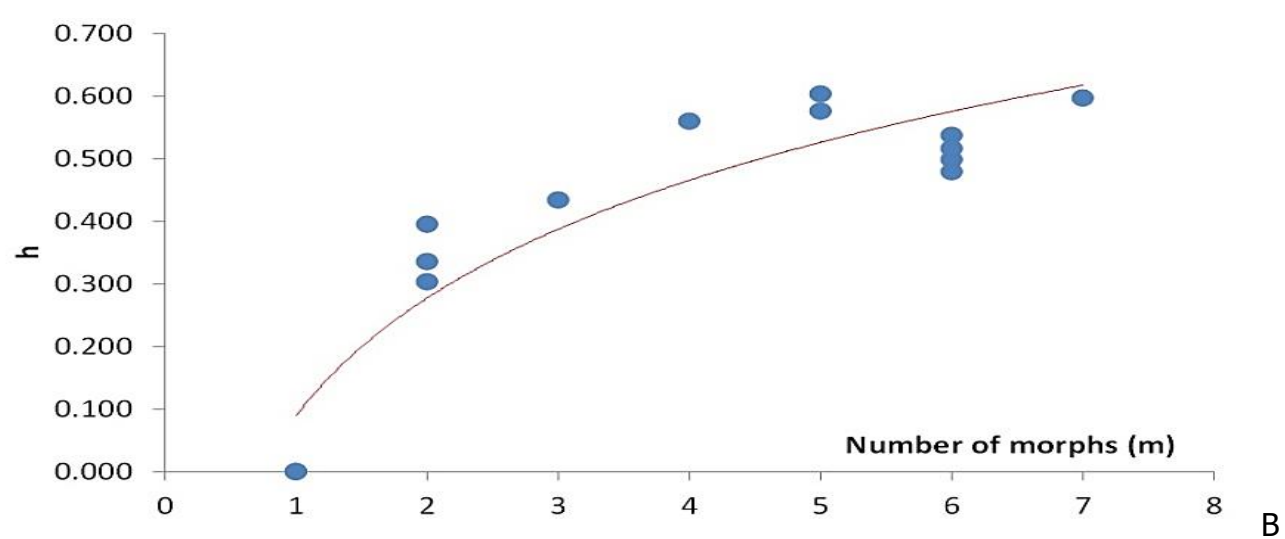

Figure 4. Dependence of rare morph frequency on sample size $(A)$ and number of morphs (B).

It was found that the type of biotope did not likely affect the frequency of individual morphs with respect to the shell banding polymorphism of the land snail $C$. vindobonensis. (In this case, a negative result may indicate both the absence of such relationship and the narrowness of the spectrum of the factor variable.)

Moran's index for the shell banding polymorphism characters within studied population of the land snail $C$. vindobonensis are presented in Figure 5. With regard to the most common morphs two patterns of the spatial arrangement of the intrapopulation variation were found - clinal pattern was for the frequency of pallescens morph (Figure $5 \mathrm{~A}$ ) and chaotic pattern was for frequency of "12345" morph (Figure 5B).

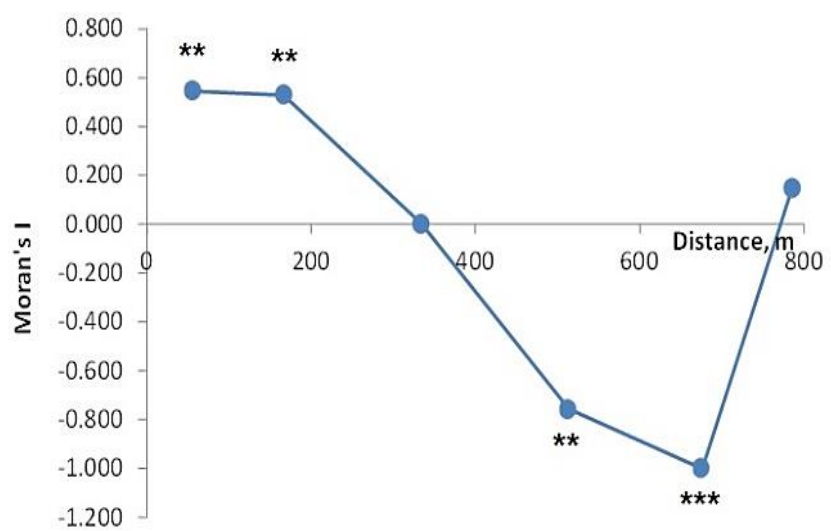

A

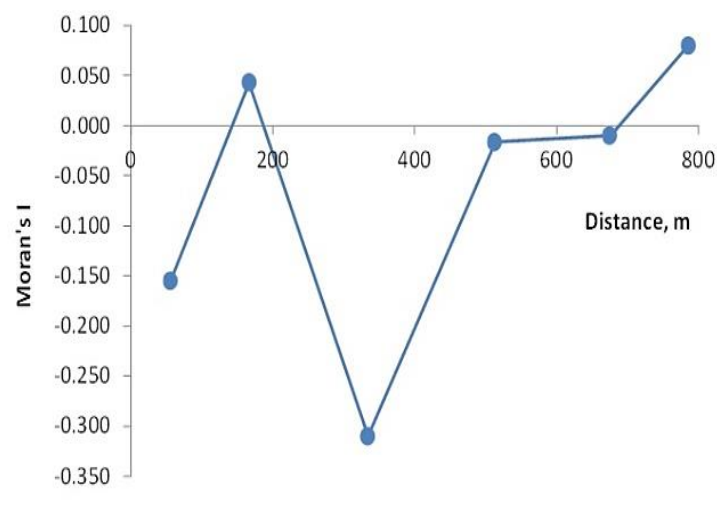

B

Figure 5. Moran's index for the frequency of pallescens moprh (A) and the "12345" morph (B) within population of C. vindobonensis. (Significant values of Moran's index indicated as solid circles: $* * P<0.01, * * * P<0.001$ ).

\section{Discussion}

A high level of the intrapopulation variation of the land snail $C$. vindobonensis within a continuous population (a metapopulation), occupying an area of about $800 \times 400 \mathrm{~m}$, was found in our study. Spatial variation in morphological traits and gene frequencies through space are common for many species of plants and animals. The heterogenic distribution of genetic variation within and between local populations is provided by the mutation events, gene drift (due to limited population size) and different forms of natural selection, while the gene flow creates the prerequisites for the formation of genetic homogeneity (Endler, 1977; Slatkin, 1987). Asphalt roads, dividing the population territory into three areas, had a significant effect of insularisation, manifesting themselves for both shell morphological traits and banding polymorphism. According to A. Baur \& B. Baur (1990), populations of the land snail Arianta arbustorum (L., 1758), separated by paved roads with high traffic densities, may be isolated from each other. They also showed in their experiment that only one of the recaptured snails crossed the paved road and two crossed the track, indicating that the road and, to a minor extent, the track acted as dispersal barriers.

The negative urban roads effect was considered in the review J. Underhill \& P. Angold (1999). They showed that the impacts of roads in the ecological landscape include habitat loss, fragmentation, and degradation. These interrupt and modify natural processes altering community structures and in the longer term, population dynamics. Besides that, road construction kills sessile and slow-moving organisms (such as land snails), injures organisms adjacent to a road, and alters physical conditions beneath a road. Vehicle collisions affect the demography of many species, both vertebrates and invertebrates (Trombulak \& Frissell, 2000).

Using another example of a large helicide, Cornu aspersum (Müller, 1774), it was shown that urban areas are highly fragmented and thereby exert strong constraints on individual dispersal and areas with a high percentage of roads decreased genetic differentiation between populations.

On the other hand, urban transport infrastructures facilitate passive snail dispersal. At a local scale, corresponding to active dispersal, unfavourable habitats (wooded and impervious areas) isolate populations (Balbi et al., 2018).

In addition, land snails can use the information potentially exploitable by conspecifics during movement (through mucus trails). As it has been recently shown with the land snail $C$. aspersum, dispersers followed mucus trails more frequently than expected by chance, contrary to non-dispersers. Trail-following by dispersers may reduce dispersal costs by reducing energy expenditure and helping snails find existing habitat or resource patches (Vong et al., 2019). 
We have noted the existence of two spatial arrangement patterns in intrapopulation variantion, which are clinal and chaotic. The manifestation of the clinal pattern of variation in conchiometric traits at a fine spatial scale (at distances of 200 ... $1000 \mathrm{~m}$ ) has been previously noted for the land snails Cepaea hortensis (Muller, 1774) (Bengtson et al., 1979) and Rhagada convicta (Cox, 1870) (Stankowski, 2011). Among other gastropod types, the formation of the clinal pattern of variation of shell traits within areas ranging from several tens to several hundred meters is also a frequent occurrence. A similar pattern was revealed, for example, for the marine gastropod mollusk Littorina striata King \& Broderip, 1832 (De Wolf et al., 1997) and for the freshwater snail Mexipyrgus churinceanus Taylor, 1966 (Hershler \&Minckley, 1986). As it is known, the formation of the clinal pattern of variation can be expected within the areas between which there is a weak or intermittent gene flow (Endler, 1977).

It is known that the formation of the clinal patterns of conchiometric variation can be connected with active and passive dispersal in the land snails (Kramarenko, 2014). According to S. Aubry et al. (2006), active dispersal in the land snails is not as limited as previously thought. The colonization of Provence (France) by the land snail Xeropicta derbentina (Krynicki 1836) occurred by stratified diffusion, where short-range active dispersal occurs side by side with long-range passive dispersal. Passive dispersal via human activities is the main determinant of $X$. derbentina distribution within the landscape.

On the other hand, breaking of the clinal pattern of variation in shell characters, when considering the fine scale, it is associated with the peculiarities of the spatial distribution of individuals and/or groups within population. In this case, a weak gene flow between individual subpopulations (especially, spatially distant) can lead to the formation of a morphological "area effect", similar to what has been described earlier for the shell colour and banding polymorphism (Cain \& Currey, 1963), as well as for allozyme polymorphism (Ochman et al., 1983). This pattern of the conchiometric variation in a micro-geographical scale (in the absence of clear differences between individual sites within continuous populations) does not necessarily reflect genetic subdivision between groups of the land snails that differ in terms of the shell shape and shell size. It can be a simple manifestation of the phenotypic plasticity of morphological traits, which is based on the polygenic inheritance and relatively high level of heritability.

On the other hand, numerous authors note the high plasticity of the conchiometric traits of the land snails, which, first of all, is reflected in the inverse relationship between shell size and population density (Dan \& Bailey, 1982; Baur, 1988; Perry \& Arthur, 1991; Anderson et al., 2007). Thus, on the micro-geographical scale, a number of ecology and demographic characteristics of species are involved in the formation of patterns of the land snail conchiometric variation, which form a complex set of cause-effect relationships against the background of fluctuations of environmental factors.

\section{Conclusion}

We registered a high level of the intrapopulation variation of the land snail $C$. vindobonensis within a continuous population (metapopulation). About $80 \%$ of the total variation of the variance-covariance matrix was explained by two Principal Components (PC1 and PC2). The PC1 was characterized by high positive factor loadings and can be interpreted as "shell size dimension" and the PC2 can be interpreted as "shell globularity". We have noted two spatial arrangement patterns in intrapopulation variantion, which are clinal and chaotic. We supposed that number of ecology and demographic species characteristics caused the land snail conchiometric variation at the micro-geographical scale.

\section{References}

Anderson, T. K., Weaver, K. F., \& Guralnick, R. P. (2007). Variation in adult shell morphology and life-history traits in the land snail Oreohelix cooperi in relation to biotic and abiotic factors. Journal of Molluscan Studies, 73(2), 129-137.

Armbruster, G. (1995). Univariate and multivariate analyses of shell variables within the genus Cochlicopa (Gastropoda: Pulmonata: Cochlicopidae). Journal of Molluscan Studies, 61(2), 225-235.

Aubry, S., Labaune, C., Magnin, F., Roche, P., \& Kiss, L. (2006). Active and passive dispersal of an invading land snail in Mediterranean France. The Journal of Animal Ecology, 75(3), 802-813.

Avaca, M. S., Narvarte, M., Martín, P., \& Van Der Molen, S. (2013). Shell shape variation in the Nassariid Buccinanops globulosus in northern Patagonia. Helgoland Marine Research, 67(3), 567-577.

Balbi, M., Ernoult, A., Poli, P., Madec, L., et al. (2018). Functional connectivity in replicated urban landscapes in the land snail (Cornu aspersum). Molecular ecology, 27(6), 1357-1370.

Baur, B. (1988). Microgeographical variation in shell size of the land snail Chondrina clienta. Biological Journal of the Linnean Society, 35(3), 247-259.

Baur, A., \& Baur, B. (1990). Are roads barriers to dispersal in the land snail Arianta arbustorum? Canadian Journal of Zoology, 68(3), 613617

Bengtson, S. A., Nilsson, A., Nordström, S., \& Rundgren, S. (1979). Selection for adult shell size in natural populations of the landsnail Cepaea hortensis (Müll.). Annales Zoologici Fennici, 16(3), 187-194.

Cain, A. J., \& Currey, J. D. (1963). Area effects in Cepaea on the Larkhill Artillery ranges, Salisbury plain. Journal of the Linnean Society of London. Zoology, 45(303), 1-15.

Cain, A. J., \& Sheppard, P. M. (1950). Selection in the polymorphic land snail Cepaea nemoralis. Heredity, 4(3), 275-294.

Chiba, S. (1998). Synchronized evolution in lineages of land snails in oceanic islands. Paleobiology, 24(1), 99-108.

Clarke, B. C., Arthur, W., Horsley, D. T., \& Parkin, D. T. (1978). Genetic variation and natural selection in pulmonate snails. The Pulmonates. 2A. Systematics, evolution and ecology (ed. V. Fretter \& J. Peake). New York: Academic Press, 1978. P. $220-270$.

Dan, N. A., \& Bailey, S. E. R. (1982). Growth, mortality, and feeding rates of the snail Helix aspersa at different population densities in the laboratory, and the depression of activity of helicid snails by other individuals, or their mucus. Journal of Molluscan Studies, 48(3), $257-265$. De Wolf, H., Backeljau, T., Medeiros, R., \& Verhagen, R. (1997). Microgeographical shell variation in Littorina striata, a planktonic developing periwinkle. Marine Biology, 129(2), 331-342.

Endler, J. A. (1977). Geographic variation, speciation, and clines. Princeton, N.J.: Princeton University Press, USA.

Funk, A., \& Reckendorfer, W. (2008). Environmental heterogeneity and morphological variability in Pisidium subtruncatum (Sphaeriidae, Bivalvia). International Review of Hydrobiology, 93(2), 188-199.

Giokas, S. (2000). Congruence and conflict in Albinaria (Gastropoda, Clausiliidae). A review of morphological and molecular phylogenetic approaches. Belgian Journal of Zoology, 130 (Suppl. 1), 93-100.

Goodfriend, G. A. (1986). Variation in land-snail shell form and size and its causes: a review. Systematic Biology, 35(2), $204-223$.

Gould, S., \& Woodruff, D. (1985). Evolution and systematics of Cerion (Mollusca: Pulmonata) on new providence Island: a radical revision. Bulletin of the American Museum of Natural History, 182(4). 389-490.

Harvey, M., \& Vincent, B. (1991). Spatial variability of length-specific production in shell, somatic tissue and sexual products of Macoma balthica in the Lower St. Lawrence Estuary. I. Small- and meso-scale variability. Marine ecology progress series. Oldendorf, 75(1), 55-66. 
Hershler, R., \& Minckley, W. L. (1986). Microgeographic variation in the banded spring snail (Hydrobiidae: Mexipyrgus) from the Cuatro Ciénegas basin, Coahuila, Mexico. Malacologia, 27, 357-374.

Hummer, O., Harper, D. A. T., \& Ryan, P. D. (2001). PAST: Paleontological Statistics Software Package for Education and Data Analysis. Palaeontologia Electronica, 4(1), 1-9.

Jordaens, K., Van Riel, P., Frias Martins, A. M., \& Backeljau, T. (2009). Speciation on the Azores islands: congruent patterns in shell morphology, genital anatomy, and molecular markers in endemic land snails (Gastropoda, Leptaxinae). Biological Journal of the Linnean Society, 97(1), 166-176.

Kramarenko, S. S. (2014). Active and passive dispersal of terrestrial mollusks: a review. Ruthenica, Russian Malacological Journal, 24(1), 114. (In Russian)

Kramarenko, S. S. (2016). Patterns of spatio-temporal variation in land snails: a multi-scale approach. Folia Malacologica, 24(3), 111-177.

Kramarenko, S. S., \& Dovgal, I. V. (2014). Spatial variation of the land snail Brephulopsis cylindrica (Gastropoda, Pulmonata, Enidae): A fractal approach. Vestnik zoologii, 48(5), 433-440.

Moran, P. A. (1950). Notes on continuous stochastic phenomena. Biometrika, 37(1/2), 17-23.

Ochman, H., Jones, J. S., \& Selander, R. K. (1983). Molecular area effects in Cepaea. Proceedings of the National Academy of Sciences, 80(13), 4189-4193.

Perry, R., \& Arthur, W. (1991). Shell size and population density in large helicid land snails. The Journal of Animal Ecology, 60(2), 409-421

Rangel, T. F., Diniz-Filho, J. A. F., \& Bini, L. M. (2010). SAM: a comprehensive application for spatial analysis in macroecology. Ecography, 33(1), 46-50.

Slatkin, M. (1987). Gene flow and the geographic structure of natural populations. Science, 236(4803), 787-792.

Sokal, R. R., \& Oden, N. L. (1978). Spatial autocorrelation in biology: 1. Methodology. Biological journal of the Linnean Society, 10(2), 199228.

Sverlova, N. V., Khlus, L. N., Kramarenko, S. S., Son, M. O., et al. (2006). Fauna, ekologiya i vnutrividovaya izmenchivost'nazemnykh mollyuskov $v$ urbanizirovannoy srede [Fauna, ecology and intraspecific variability of the terrestrial molluscs in an urban environment]. Lviv: National Museum of Natural History at the NAS of Ukraine (in Russian).

Stankowski, S. (2011). Extreme, continuous variation in an island snail: local diversification and association of shell form with the current environment. Biological Journal of the Linnean Society, 104(4), 756-769.

Trombulak, S. C., \& Frissell, C. A. (2000). Review of ecological effects of roads on terrestrial and aquatic communities. Conservation biology, 14(1), 18-30.

Underhill, J. E., \& Angold, P. G. (1999). Effects of roads on wildlife in an intensively modified landscape. Environmental Reviews, 8(1), 2139.

Van Marion, P. (1981). Intra-population variation of the shell of Littorina rudis (Maton) (Mollusca: Prosobranchia). Journal of Molluscan Studies, 47(1), 99-107.

Vong, A., Ansart, A., \& Dahirel, M. (2019). Dispersers are more likely to follow mucus trails in the land snail Cornu aspersum. The Science of Nature, 106(7-8), 43.

Woodruff, D. S., \& Gould, S. J. (1980). Geographic differentiation and speciation in Cerion - a preliminary discussion of patterns and processes. Biological journal of the Linnean Society, 14(3-4), 389-416.

Underhill, J. E., \& Angold, P. G. (1999). Effects of roads on wildlife in an intensively modified landscape. Environmental Reviews, 8(1), 2139.

Yusseppone, M. S., Márquez, F., Luquet, C. M., Brey, T., Ríos de Molina, M. C., \& Rocchetta, I. (2018). Does shell shape variation play a role in conservation of the long-lived freshwater bivalve Diplodon chilensis (Bivalvia, Hyriidae)? Ecohydrology, 11(2), e1931.

Zhivotovsky, L.A. (1991). Population Biometrics. Moscow: Nauka Publishing.

Zhukov, O. V., Kovalenko, D. V., Kramarenko, S. S., \& Kramarenko, A. S. (2019). Analysis of the spatial distribution of the ecological niche of the land snail Brephulopsis cylindrica (Stylommatophora, Enidae) in technosols. Biosystems Diversity, 27(1), 62-68.

\section{Citation:}

Kramarenko, A.S., Ignatenko, Zh.V., Yulevich, O.I., Barkar, Y.V., Markowska, A.V., Salamatina, O.O., Stamat, V.M., Kramarenko, S.S. (2020). Intrapopulation variation in shell morphological traits and banding polymorphism of the land snail Cepaea vindobonensis (Gastropoda; Pulmonata; Helicidae). Ukrainian Journal of Ecology, 10(5), 114-121. 